\title{
Immunocytochemical localisation of arabinoxylans in the cell walls of maize stem and their fate after incubation in the rumen
}

\author{
C Migné ${ }^{1}$, G Prensier ${ }^{2}$, E Grenet ${ }^{1}$ \\ 1 INRA, Station de Recherches sur la Nutrition des Herbivores, Theix, \\ 63122 Saint-Genès-Champanelle; \\ 2 Université Blaise-Pascal, Laboratoire de Microbiologie, 63177 Aubière, France
}

The hemicelluloses, which consist mainly of arabinoxylans in graminae, are bound to lignin, thus inhibiting their degradation in the rumen. Having detected the presence of arabinoxylans in the cell walls by an immunocytochemical technique (Barry et al, 1991), we decided to study their fate in the rumen. The base and the top of the upper internode of Co125 maize were used. Their digestibility in sacco was 87 and $72 \%$ respectively. Digestibility varies inversely with the lignification and maturity gradients in the internode. Immunocytochemical labelling was performed on samples before and after incubation in sheep rumen for $8 \mathrm{~h}$. Specific antibodies were prepared against oat arabinoxylans to detect their presence by immunogold labelling in cell walls. Three rabbits were immunized by intravenous injections of antigen. Ultrathin sections of maize stem on nickel grids were first incubated with a blocking solution of ovalbumin, then with primary antiserum, and finally with protein A gold complex. The specificity of the antigen was determined: no labelling with preimmune serum, none with protein A gold complex alone and no cross-reactivity with the other main constituents of the cell wall. A quantitative evaluation of the number of gold particles (indicating the presence of arabinoxylans) per $\mathrm{cm}^{2}$ of cell wall was performed. The tissues from the top were more heavily labelled than those from the base (table I). In the top, the parenchyma was less labelled than the lignified tissues: sclerenchyma, fibres and xylem. These results are in agreement with those of Jarrige (1963) on the arabinoxylan content of the various tissues and on the evolution of the composition of graminae with age. After $8 \mathrm{~h}$ incubation in the rumen of the top of the internode, the density of labelling decreased in the sclerenchyma and the fibres (table I), probably due to the disappearance of the arabinoxylans from these tissues. At the same time, the density of labelling increased in the lignified tissues from the base, probably because some specific sites were unmasked during rumen degradation. The standard deviations of the means concerning the labelling of the parenchyma are high because the labelling of this tissue is weak and scattered. Immunocytochemical localisation of arabinoxylans in plant cell walls is of interest in the study of the control factors of the microbial degradation of cell walls. The localisation of the other cell-wall components involved in carbohydrate-lignin bonds (phenolic acids) will be useful for studying these mechanisms.

Barry P, Prensier G, Grenet E (1991) Biol Cell $71,307-311$

Jarrige R (1963) Ann Biol Anim Bioch Biophys $3,143-190$

Table 1. Quantification of the labelling of cell wall (number of gold particles per $\mathrm{cm}^{2}$ ) in the top and the base of apical internode of Co125 maize before $(0 h)$ and after $(8 h)$ incubation in the rumen.

\begin{tabular}{|c|c|c|c|c|}
\hline \multirow[t]{2}{*}{ Tissue } & \multicolumn{2}{|c|}{$O h$} & \multicolumn{2}{|c|}{$8 h$} \\
\hline & Top & Base & Top & Base \\
\hline S & $7.0 \pm 1.7$ & $4.6 \pm 3.0$ & $5.6 \pm 2.0$ & $6.7 \pm 1.4$ \\
\hline$x$ & $6.2 \pm 1.4$ & $2.2 \pm 1.2$ & $8.0 \pm 2.3$ & $6.4 \pm 1.1$ \\
\hline $\mathbf{F}$ & $8.4 \pm 2.8$ & $3.0 \pm 0.9$ & $5.3 \pm 2.4$ & $4.9 \pm 1.2$ \\
\hline $\mathbf{P}$ & $0.9 \pm 0.7$ & $6.6 \pm 3.0$ & $2.3 \pm 1.8$ & $2.4 \pm 2.7$ \\
\hline
\end{tabular}

S: sclerenchyma; $X$ : xylem; $F$ : fibres; and $P$ : parenchyma. 